\title{
Informal Sector Employment and Consumption Patterns in China*
}

\author{
Junzi He \\ Central University of Finance and Economics, Beijing, China \\ Bo $\mathrm{Li}$ \\ Peking University, Beijing, China
}

\begin{abstract}
The paper investigates how workers employed in informal sector will affect household consumption patterns, and how such patterns vary across different income distribution. China Household Finance Survey (CHFS) dataset is well qualified for this research and empirical results show that families where wives are informal employed tend to reduce their expenditure on time-saving goods and time-consuming goods, while there is a significant raise if the husbands are informal employed. For necessities, families with wives working in formal sector enjoy much better fringe benefits. Richest families are not as much constrained as those in poorest families due to less budget constraint as well as time constraint. In addition, concerning the demographic characteristics of the household members, especially the educational attainment, both female and male spouse have positive impacts on the time-saving and time-intensive goods, while there is not significant effect on time-neutral goods. The presence and age of children in the household have a significant effect on time-saving goods. The household subjective factors play an important role on expenditure on time-saving goods, especially for the poorest household.
\end{abstract}

Keywords: informal sector employment, consumption pattern, income quantile, empirical analysis

During the past three decades, China has achieved unprecedented economic growth and social development, the consumption patterns for Chinese people have also changed remarkably. People tend to spend less on basic daily necessities but more on traveling, IT products, housing, medical insurance, entertainment, which helps to promote the catering and tourism sectors. For each individual, two factors contribute to their consumption decision. Employment status is the first one. Due to the reason that China's labor market is not homogeneous, there exists large amount of employment in informal sector. This phenomenon will influence household income and their temporal restriction, so the composition of goods demanded by the whole family will be affected. The second factor is income distribution. The consumption-choice criteria as well as consumption patterns of higher income consumers are generally different from those with lower income

\footnotetext{
* The authors would like to express their thanks for the financial support of China Scholarship Council and China Postdoctoral Science Foundation (Project No. 2016M590001).

Corresponding author: Junzi He, Ph.D. candidate, research assistant, China Center for Human Capital and Labor Market Research, Central University of Finance and Economics, Beijing, China; research fields: labor economics, micro econometrics, education economics.

Bo Li, post-doc, School of Economics, Peking University, Beijing, China; research fields: development economics, labor economics, macroeconomics and micro applied economics.
} 
consumers. Individuals belonging to different income levels will also have different uncertain expectation of future household expenditure, which in turn has an impact on their consumption in current period.

This paper focuses on the consumption patterns in respect of employment status and income distribution. A first attempt is made to explore the impact of informal sector employment of household members on the family consumption patterns. The questions of interest are as follows: first, whether those family members who participate in informal sector present differential consumption patterns with those in formal employment status. Second, how difference the impact of employment status on expenditure of typical goods and services across different family income quantile is.

The paper is structured as follows: The next Section 2 summarizes the existing literature and provides theoretical framework and the hypotheses tested in the paper. Section 3 describes the data, definition of variables, and methodologies used. In Section 4, the authors analyze empirical result. Finally, some conclusions and policy implications are given in Section 5 .

\section{Literature and Theoretical Framework}

This section presents a review of the literature and sheds some light on the theoretical framework of the link between employment status and consumption patterns. While a wealth of research has been conducted on the Chinese economy and society, there is a relative paucity of research on mainland Chinese consumer behavior through various bibliographic databases. Many studies tried to find out consumption patterns by addressing the factor of segmentation of mainland China (see Chen, Aung, Zhou, \& Kanetkar, 2005; Dickson, Lennon, Montalto, Shen, \& Zhang, 2004; Sun \& Wu, 2004; Cui \& Liu, 2000). Some studies on Chinese consumer behavior have focused on a particular subset of the entire population, especially the urban consumers (see Wei, 1997; Sun, Chang, \& Yu, 2001). Other research papers dealt with specific expenditure categories such as food (see Ma, Huang, Fuller, \& Rozelle, 2006; Gould \& Villarreal, 2006; Min, Fang, \& Li, 2004) and specific age groups such as elder (see Ying \& Yao, 2006). On the other hand, many of the existing literatures have concentrated on consumption classes and expenditure on different commodities (see Yusuf \& Brooks, 2010; Yusuf \& Wu, 1997). However, almost none of the existing literature concerns on consumption patterns in respect of employment status in China, especially the impact of informal employment.

With the high speed of urbanization in late 1980s in China, massive immigrants have flooded from rural to urban areas. Those immigrants find it hard to be employed in formal sector because of skill mismatch and "hukou" system restriction. Also with the economic transformation from plan economy to market-oriented economy, a great number of laid-off workers from own-stated enterprise or collective enterprise have to face reemployment. Then informal sector provides a channel to absorb the spillover jobless of the formal sector. "Informal sector" is a commonly used term in development economics, which is characterized as "low wage", "small and family-based", "freedom of entry", "lack of a stable employer-employee relationship", and "being ignored by the authorities" [Todaro, 1969; Fields, 1975; Mazumdar, 1977; International Labour Office (ILO), 1984; Banerjee, 1983]. In this paper, the authors define informal employment based on the survey of China Household Finance Survey (CHFS) 2011 and it will be introduced in details later. Specifically, the authors are particularly interested in estimating the impact of informal sector employment and household expenditure on three different types of goods: (1) catering services, they are time-saving goods or income-intensive goods; (2) entertainment services which are time-consuming goods or time-intensive goods; (3) necessities which we can expect are not time-consuming for the family members. 
The authors concern on the effect of employment status on time constraint and budget constraint of household in order to find some empirical evidence on the impact of informal employment on consumption patterns. The authors will not only investigate the differential impact of employment status but also analyze it in great details by observing the differential effect on expenditure across different household income distribution. In addition, the authors will also consider the effect of some demographic variables and the employment situation by gender. The theoretical rationality is summarized as follows:

Firstly, employment type is highly correlated with labor income which determines the time constraint as well as budget constraint. Formal employments and informal employments face different time constraint no matter in working or job searching. Those working in informal sector have more flexible working schedule and less commuting. As for budget constraint, employees who are in formal sector, especially in state-owned enterprise (SOE) enjoy many more fringe benefits such as welfare and subsidies or bonus, which compose the most part of non-labor income. Individual decision of consumption is a multi-periods decision which will also be affected by expectation for next period. Many of those workers in informal sector are normally temporary workers which means they have much higher possibilities to be fired than those worked in formal sector. Such uncertainty will lead them to be more precautionary saving but not for consuming. One phenomenon which cannot be ignored is gender discrimination in labor market especially in developing countries. In general, female finds it harder to receive the offer from formal sector than male. Even in the same position, the payment is lower for female, the barriers and window-celling effect also halt women's career path. Such discriminations in labor market lead to different behavior in consumption. Women are less likely to spend on income-intensive goods, while male will consume more on time-saving goods. In addition, women are burdened with child care and housework, the allocation and preference of time and income will be totally different with men.

Secondly, consumption decision will show different patterns among different income quantiles. For poorest families, basic necessities are of the utmost urgency to maintain living, while for the richest, more attention may be put on tourist or entertainment activities. Such patterns will also be affected by employment types, because salaries and social security system are well-provided in formal sector, lower income families in formal sector will not worry so much compared with those in informal sector because lower risk there will be in the future. While workers in informal sector have much more instability, they may weight more time on searching stable job and consume more on time-saving goods and services.

Thirdly, consumption patterns are also affected by demographic characteristics such as age, education level, and geographical location, especially for those married couple. Specifically, the composition of families will affect household production function. The presence and age of children are expected to cause "optimal choice" with respect to labor supply of family members. Childcare can be treated as a commodity in household production function, individual working in different employment types and families standing in different income distribution will have different substitution effect in terms of time and money. Families with younger children will tend to reduce the expenditure on leisure goods and services but increase it when children grow up. With the population aging, tourist and entertainment industries share a large benefit from grey market. Especially for those who worked in formal sector, they may have higher preference on it since more disposable time is now available after retirement.

\section{Data and Variables}

Recent data containing information on labor force participation, consumption patterns, earnings, and 
socioeconomic characteristics of households are available in the CHFS 2011. This survey tends to be very good data source of household income and expenditure. In addition, it provides full information on household subjective attitude which also plays a very important role on investigating consumption including consumption preference, time preference, and future economy forecast. The data source is unique in that sense. In addition, it presents more detailed information to categorize informal employment in China. The definition of informal employment based on CHFS refers to the classical definition of informal employment, the authors define informal employment with following criterion: (1) the person who is not in charge of the enterprise; (2) the person whose post is not cadre; (3) the person who is not employed by following initial plan and does not accord with the regular system; (4) the person who is employed without any insurance. Except for that, the authors also classify self-employment status in the domain of informal employment. The authors can then use the group of household formed by married couple where the female group is included into the group of age of 16-55 and the male group is included into the group of age 16-60. The variable statistic descriptions are shown in Table 1.

Table 1

Statistics Summary for Key Variables by Household Income Quantile

\begin{tabular}{|c|c|c|c|c|c|c|c|c|c|c|c|c|}
\hline Variable & Mean & $\begin{array}{l}\text { Std. } \\
\text { Dev. }\end{array}$ & Min & Max & Mean & $\begin{array}{l}\text { Std. } \\
\text { Dev. }\end{array}$ & Min & $\operatorname{Max}$ & Mean & $\begin{array}{l}\text { Std. } \\
\text { Dev. }\end{array}$ & Min & Max \\
\hline & \multicolumn{4}{|c|}{ Poorest $20 \%$ family } & \multicolumn{4}{|c|}{ Richest $20 \%$ family } & \multicolumn{4}{|c|}{ Middle $60 \%$ family } \\
\hline Ratio_catering & 0.0586 & 0.0979 & 0 & 0.5309 & 0.1105 & 0.1024 & 0 & 0.5096 & 0.0890 & 0.1055 & 0 & 0.6702 \\
\hline Ratio_entertainment & 0.0053 & 0.0141 & 0 & 0.0850 & 0.0221 & 0.0408 & 0 & 0.4020 & 0.0085 & 0.0213 & 0 & 0.2789 \\
\hline Ratio_necessities & 0.0312 & 0.0335 & 0 & 0.3469 & 0.0307 & 0.0369 & 0 & 0.2893 & 0.0327 & 0.0368 & 0 & 0.3072 \\
\hline EDHS & 0.6885 & 0.4640 & 0 & 1 & 0.2824 & 0.4510 & 0 & 1 & 0.5684 & 0.4956 & 0 & 1 \\
\hline EDHH & 0.1615 & 0.3687 & 0 & 1 & 0.6870 & 0.4646 & 0 & 1 & 0.3714 & 0.4835 & 0 & 1 \\
\hline AGEH2 & 0.2115 & 0.4092 & 0 & 1 & 0.3168 & 0.4661 & 0 & 1 & 0.2823 & 0.4504 & 0 & 1 \\
\hline AGEH3 & 0.4423 & 0.4976 & 0 & 1 & 0.3588 & 0.4806 & 0 & 1 & 0.4065 & 0.4915 & 0 & 1 \\
\hline AGEH4 & 0.7154 & 0.4521 & 0 & 1 & 0.5840 & 0.4938 & 0 & 1 & 0.6412 & 0.4800 & 0 & 1 \\
\hline AGEH5 & 0.0115 & 0.1070 & 0 & 1 & 0.0076 & 0.0872 & 0 & 1 & 0.0100 & 0.0997 & 0 & 1 \\
\hline IFEMH & 0.5500 & 0.4985 & 0 & 1 & 0.1679 & 0.3745 & 0 & 1 & 0.1907 & 0.3931 & 0 & 1 \\
\hline IFEMW & 0.5692 & 0.4961 & 0 & 1 & 0.1450 & 0.3528 & 0 & 1 & 0.2045 & 0.4036 & 0 & 1 \\
\hline FEMH & 0.4500 & 0.4985 & 0 & 1 & 0.8321 & 0.3745 & 0 & 1 & 0.8093 & 0.3931 & 0 & 1 \\
\hline FEMW & 0.4308 & 0.4961 & 0 & 1 & 0.8550 & 0.3528 & 0 & 1 & 0.7955 & 0.4036 & 0 & 1 \\
\hline EDWS & 0.6615 & 0.4741 & 0 & 1 & 0.3015 & 0.4598 & 0 & 1 & 0.6010 & 0.4900 & 0 & 1 \\
\hline EDWH & 0.1385 & 0.3460 & 0 & 1 & 0.6489 & 0.4782 & 0 & 1 & 0.3099 & 0.4627 & 0 & 1 \\
\hline AGEW2 & 0.2192 & 0.4145 & 0 & 1 & 0.3817 & 0.4867 & 0 & 1 & 0.3187 & 0.4663 & 0 & 1 \\
\hline AGEW3 & 0.4615 & 0.4995 & 0 & 1 & 0.3015 & 0.4598 & 0 & 1 & 0.4166 & 0.4933 & 0 & 1 \\
\hline AGEW4 & 0.6731 & 0.4700 & 0 & 1 & 0.4924 & 0.5009 & 0 & 1 & 0.5834 & 0.4933 & 0 & 1 \\
\hline Obs & 260 & & & & 262 & & & & 797 & & & \\
\hline
\end{tabular}

In order to estimate the Tobit equations for different groups of goods and services, the authors have the relevant information about the Chinese household's expenditure of three subgroups: "catering services", "entertainment service", and "necessities goods". The dependent variables are defined as the ratio among the

\footnotetext{
${ }^{1}$ One of the important features of this kind of consumption model and its econometric implementation is the treatment of zero expenditure. That happens when we have corner solutions for a number of families. When we have this type of sample, it is convenient to estimate through a Tobit model. In some case, the sign of the effect of the above-mentioned factors, on the expenditure of goods and services will depend on whether the good is time-intensive or time-saving or neutral.
} 
expenditure on catering service, on entertainment service (magazines, newspapers, and reviews), and on necessities, with respect to the total expenditure of the household respectively.

The explanatory variables are defined as follows: The age of men is a set of the five dummies: men 16-25 (AGEH1), and serves as reference group; men 26-35 (AGEH2); men 36-45 (AGEH3); men 46-55 (AGEH4); men 55 above (AGEH5). The age of women is also a set of four dummies: women 16-25 (AGEW1), is reference group; women 26-35 (AGEW2); women 36-45 (AGEW3); women 46-55 (AGEW4). Education of the male partner is a set of dummies: the reference category is primary education (EDHP); secondary education (EDHS); higher education (EDHH). Similarly with education of female partner, the reference category is primary education (EDWP); secondary education (EDWS); higher education (EDWH). Total household members are a quantitative variable (FAMEMBER). Employment situation has two categories: formal employed (reference category), informal employed (IFEMH). Age of children is a set of four dummies: there are children 0-2 years old in the household (AGECHILD1); there are children 3-6 years old in the household (AGECHILD2); there are children 7-12 years old in the household (AGECHILD3); there are children 13-18 years old in the household (AGECHILD4). The reference category is the household where there is no child in the corresponding age group. Age of elder is a set of two dummies: there are elder 60-80 years old in the household (AGELDER1); there are elder above 80 years old in the household (AGELDER2). The reference category is the household where there are no elders in the corresponding age group. Household income is a quantitative variable (HHINCOME) measuring the total household income. Household subjective attitude includes: two dummies measuring consumption preference: willing to consume (WCONSUME); unwilling to consume (UWCONSUME); the reference category is neutral attitude for consuming. Two dummies measuring forecast on interest rate: expect to increase (IRUP); expect to decrease (IRDOWN); the reference category is the unchanged expectation of interest rate. Two dummies measuring economy forecast: expect to boom (ECBOOM); expect to recessive (ECRECESSIVE); the reference category is unchanged expectation of economy status. Last one is time preference dummies: willing to pay this year (TIMEPRE); the reference category is willing to pay next year.

\section{Estimation Results}

From the following regression results which are reported in Table 2, we can find how informal sector employment will affect household expenditure, and how those consumption patterns vary among different family income quantiles. The first three columns show the regression result of household expenditure on three groups of goods and services: catering, entertainment, and necessities. The key variable of our interest is the employment status of their spouse and all the other explanatory variables remain the same for the three groups, and the sample bias problem is addressed by introducing the Inverse Mills Ratio (IMR) to the censored regression.

Families with male working in informal sector will spend 2.2\% more on catering compared with those in formal sector, and it is significant under $10 \%$ significant level. But with female partner working in informal sector, the expenditure on catering is significantly $2.63 \%$ lower than those in formal sector. One possible reason is that male has more bargaining power and dominates the consumption choice on eating out. The positive sign for male partner and negative sign for female partner remain the same with expenditure on entertainment but the effect is not much significant. As with necessities, still, male dominates female on consumption choice, 
informal employment male prefers to have less $0.56 \%$ expenditure on necessities. Such patterns demonstrate the fringe benefit effect in formal sector is widespread. Compared to reference group with primary education, there is no significant difference on necessities, but for husbands who work in informal sector will have $6.29 \%$ higher expenditure on catering service. Both husband and wife who are employed in informal sector have significant higher consumption on entertainment service, especially with higher education. It shows that people with higher education have higher payment and can afford time-consuming service. For age group, male workers between 36-45 years old in informal sector have $0.996 \%$ higher expenditure on entertainment service, while female workers between $46-55$ years old have $4.79 \%$ lower expenditure on catering. It is consistent with career path development because male needs more social activities to build interpersonal network. For demographic variables, only families having children with $0-2$ years old have $4.15 \%$ lower on catering since the children are too young to eat out. The age dummies of elders in the household have no significant effect on expenditure of any goods and services.

There is positive impact of total household income on expenditure of all the goods and services except the expenditure of catering. Household income has a significantly positive impact on entertainment services. In contrast, the income effect on necessities is significantly negative. This being in line with the Engel's Coefficient states that families with more money will spend less on food. The attitude of future economy forecast will also affect consumption choice. Household which is unwilling to consume tends to spend less $2.85 \%$ and $1.15 \%$ on catering and entertainment respectively than those with neutral attitude. But the household with positive attitude inclines to spend $0.044 \%$ less on necessities than those with neutral attitude. It shows the elasticity for necessities is smaller than entertainment and catering.

Without considering income distribution, the authors can summarize that there is significantly different gender preference on consumption patterns in informal sector. Families with those wives who are informal employed tend to reduce expenditure on time-saving goods, but opposite effect occurs if their husbands are informal employed. This indicates a different allocation of time by male and female spouses within the household. Presumably, informal women spouses tend to devote most of their time to housework, while men make use of their time searching for stable jobs or increasing their earnings. The significant and negative impact of informal employment on the expenditure of necessities for male shows that male dominates family budget.

In the following part, the authors want to investigate how the differential impact of employment status on consumption patterns across household income distribution is. This will give the authors more detailed evidence that how the informal employment affects the expenditure of different goods and services. The authors divided the population into different sized groups in the order of poorest to richest. The household income shares are in the measurement of income distribution, including low income, middle income, and high income household. Those households with income shares below $20 \%$ are categorized for poorest income group and above $20 \%$ are treated as richest income group. The households which account for $60 \%$ income shares are the middle income group.

The result of the regression of household expenditure on groups of goods and services across household income quantile is shown in Table 2. Similarly, all the regression equations have the same set of repressors and they are estimated separately for each type of goods and services. The authors will first comment on the impact of the various factors considered here about catering services, which are time-saving commodities. 
Table 2

Regression Results for Ratio of Catering, Entertainment, Necessities to Total Expenditure in Different Income Quantile

\begin{tabular}{|c|c|c|c|c|c|c|c|c|c|c|c|c|}
\hline & \multicolumn{3}{|c|}{$\begin{array}{l}\text { Ratio of catering, entertainment and necessities } \\
\text { to total expenditure }\end{array}$} & \multicolumn{3}{|c|}{ Budget share of catering service } & \multicolumn{3}{|c|}{ Budget share of entertainment service } & \multicolumn{3}{|c|}{ Budget share of necessities } \\
\hline & Catering & Entertainment & Necessities & $\begin{array}{l}\text { Income quantile } \\
20 \% \\
\text { below } \\
\end{array}$ & $\begin{array}{l}\text { Income } \\
\text { quantile } \\
80 \% \text { above } \\
\end{array}$ & $\begin{array}{l}\text { Income quantile } \\
60 \% \\
\text { middle } \\
\end{array}$ & $\begin{array}{l}\text { Income quantile } \\
20 \% \\
\text { below } \\
\end{array}$ & $\begin{array}{l}\text { Income } \\
\text { quantile } \\
80 \% \text { above }\end{array}$ & $\begin{array}{l}\text { Income quantile } \\
60 \% \\
\text { middle } \\
\end{array}$ & $\begin{array}{l}\text { Income quantile } \\
20 \% \\
\text { below }\end{array}$ & $\begin{array}{l}\text { Income } \\
\text { quantile } \\
80 \% \text { above }\end{array}$ & $\begin{array}{l}\text { Income } \\
\text { quantile } \\
60 \% \text { middle }\end{array}$ \\
\hline \multirow[t]{2}{*}{ IFEMH } & $0.0220^{*}$ & 0.00526 & $-0.00563^{* *}$ & $0.0690^{* *}$ & 0.0398 & 0.0181 & $0.0176^{* *}$ & -0.00998 & 0.000121 & 0.00591 & $-0.0239^{* * *}$ & $-0.00765^{* *}$ \\
\hline & $(-0.0121)$ & $(-0.00458)$ & $(-0.00284)$ & $(0.0285)$ & $(0.0282)$ & $(0.0154)$ & $(0.00831)$ & $(0.0151)$ & $(0.00467)$ & $(0.00486)$ & $(0.00911)$ & $(0.00385)$ \\
\hline \multirow[t]{2}{*}{ IFEMW } & $-0.0263^{* *}$ & -0.00693 & 0.0029 & $-0.0609^{* *}$ & -0.0293 & -0.00716 & $-0.0178^{* *}$ & 0.00713 & -0.00103 & -0.00304 & $0.0189^{*}$ & 0.00497 \\
\hline & $(-0.0133)$ & $(-0.00516)$ & $(-0.00311)$ & $(0.0289)$ & $(0.0307)$ & $(0.0173)$ & $(0.00841)$ & $(0.0140)$ & $(0.00613)$ & $(0.00489)$ & $(0.0106)$ & $(0.00440)$ \\
\hline \multirow[t]{2}{*}{ EDHS } & 0.0262 & $0.0178^{*}$ & 0.00596 & $0.109^{* *}$ & $-0.244^{* * *}$ & 0.00156 & 0.0198 & -0.00627 & -0.000186 & 0.0132 & 0.000856 & 0.00311 \\
\hline & $(-0.0262)$ & $(-0.00923)$ & $(-0.00463)$ & $(0.0467)$ & $(0.0787)$ & $(0.0346)$ & $(0.0127)$ & $(0.0183)$ & $(0.00913)$ & $(0.00974)$ & $(0.00971)$ & $(0.00525)$ \\
\hline \multirow[t]{2}{*}{ EDHH } & $0.0629^{* *}$ & $0.0275^{* * *}$ & 0.00487 & $0.191^{* * *}$ & $-0.225^{* * *}$ & 0.0337 & $0.0301^{* *}$ & -0.00621 & 0.00655 & 0.00643 & 0.00634 & 0.00143 \\
\hline & $(-0.028)$ & $(-0.00981)$ & $(-0.005)$ & $(0.0600)$ & $(0.0799)$ & $(0.0367)$ & $(0.0145)$ & $(0.0191)$ & $(0.00974)$ & $(0.00964)$ & $(0.0117)$ & $(0.00598)$ \\
\hline \multirow[t]{2}{*}{ EDWS } & -0.00364 & 0.0107 & -0.0065 & $0.105^{* *}$ & 0.0540 & -0.0392 & $0.0207^{* *}$ & -0.0222 & 0.00856 & -0.0124 & -0.00800 & -0.00545 \\
\hline & $(-0.0219)$ & $(-0.00694)$ & $(-0.00449)$ & $(0.0464)$ & $(0.0557)$ & $(0.0277)$ & $(0.0103)$ & $(0.0157)$ & $(0.00814)$ & $(0.00772)$ & $(0.00835)$ & $(0.00490)$ \\
\hline \multirow[t]{2}{*}{ EDWH } & 0.00661 & $0.0293^{* * *}$ & -0.00637 & $0.149^{* *}$ & 0.0284 & -0.0225 & $0.0242^{*}$ & -0.00657 & $0.0268^{* * *}$ & -0.0168 & -0.00989 & -0.00490 \\
\hline & $(-0.0242)$ & $(-0.0077)$ & $(-0.00504)$ & $(0.0597)$ & $(0.0573)$ & $(0.0305)$ & $(0.0125)$ & $(0.0171)$ & $(0.00904)$ & $(0.0108)$ & $(0.0100)$ & $(0.00590)$ \\
\hline \multirow[t]{2}{*}{ AGEH2 } & -0.0186 & -0.000487 & 0.00162 & -0.0105 & -0.0469 & -0.0101 & 0.00871 & -0.0148 & 0.00156 & 0.00733 & 0.00437 & -0.000755 \\
\hline & $(-0.0172)$ & $(-0.00964)$ & $(-0.00452)$ & $(0.0604)$ & $(0.0316)$ & $(0.0222)$ & $(0.0143)$ & $(0.0219)$ & $(0.00862)$ & $(0.00837)$ & $(0.0114)$ & $(0.00596)$ \\
\hline \multirow[t]{2}{*}{ AGEH3 } & -0.00859 & $0.00996^{*}$ & 0.00449 & -0.00735 & $-0.0583^{* *}$ & 0.00127 & 0.00166 & 0.00713 & 0.00860 & 0.0141 & 0.00105 & 0.000537 \\
\hline & $(-0.0156)$ & $(-0.00523)$ & $(-0.00382)$ & $(0.0467)$ & $(0.0289)$ & $(0.0207)$ & $(0.0150)$ & $(0.0104)$ & $(0.00545)$ & $(0.00878)$ & $(0.00687)$ & $(0.00485)$ \\
\hline \multirow[t]{2}{*}{ AGEH4 } & -0.023 & -0.0122 & -0.0025 & 0.0845 & -0.0338 & -0.0149 & 0.0336 & $-0.0385^{*}$ & -0.00346 & -0.00998 & 0.000818 & 0.00252 \\
\hline & $(-0.0244)$ & $(-0.0112)$ & $(-0.00614)$ & $(0.0855)$ & $(0.0407)$ & $(0.0324)$ & $(0.0257)$ & $(0.0231)$ & $(0.00985)$ & $(0.0126)$ & $(0.0107)$ & $(0.00866)$ \\
\hline \multirow[t]{2}{*}{$\begin{array}{l}\text { AGEH5 } \\
\text {. }\end{array}$} & -0.0734 & 0.00529 & $0.0349^{*}$ & -0.0824 & -0.0496 & -0.0881 & -0.150 & -0.0237 & 0.00738 & 0.00374 & -0.0180 & $0.0678^{* *}$ \\
\hline & $(-0.0634)$ & $(-0.0175)$ & $(-0.019)$ & $(0.0510)$ & $(0.0509)$ & $(0.0957)$ & $(0.0241)$ & $(0.0258)$ & $(0.0212)$ & $(0.0225)$ & $(0.0148)$ & $(0.0264)$ \\
\hline \multirow[t]{2}{*}{$\begin{array}{l}\text { AGEW2 } \\
\text {. }\end{array}$} & -0.0142 & -0.00451 & -0.00134 & 0.0269 & 0.0112 & -0.0183 & -0.00770 & 0.00120 & -0.00599 & $-0.0103^{*}$ & -0.0187 & 0.00405 \\
\hline & $(-0.0156)$ & $(-0.007)$ & $(-0.0047)$ & $(0.0519)$ & $(0.0252)$ & $(0.0202)$ & $(0.0115)$ & $(0.0138)$ & $(0.00874)$ & $(0.00582)$ & $(0.0140)$ & $(0.00566)$ \\
\hline \multirow[t]{2}{*}{ AGEW3 } & 0.0142 & -0.00196 & -0.00322 & 0.0642 & 0.0134 & 0.0383 & 0.0233 & -0.00432 & -0.000657 & 0.000986 & $-0.0200^{* *}$ & -0.000350 \\
\hline & $(-0.0178)$ & $(-0.00548)$ & $(-0.00421)$ & $(0.0537)$ & $(0.0286)$ & $(0.0241)$ & $(0.0168)$ & $(0.0100)$ & $(0.00636)$ & $(0.00903)$ & $(0.00818)$ & $(0.00580)$ \\
\hline \multirow[t]{2}{*}{ AGEW4 } & $-0.0479^{*}$ & -0.00233 & -0.00691 & -0.107 & -0.0120 & $-0.0858^{* * *}$ & $-0.0410^{*}$ & -0.00981 & 0.0000499 & 0.000800 & -0.0175 & -0.00859 \\
\hline & $(-0.0246)$ & $(-0.00847)$ & $(-0.00638)$ & $(0.0825)$ & $(0.0386)$ & $(0.0326)$ & $(0.0213)$ & $(0.0152)$ & $(0.0103)$ & $(0.0108)$ & $(0.0148)$ & $(0.00870)$ \\
\hline
\end{tabular}


Table 2 continued

\begin{tabular}{|c|c|c|c|c|c|c|c|c|c|c|c|c|}
\hline & \multicolumn{3}{|c|}{$\begin{array}{l}\text { Ratio of catering, entertainment and necessities } \\
\text { to total expenditure }\end{array}$} & \multicolumn{3}{|c|}{ Budget share of catering service } & \multicolumn{3}{|c|}{ Budget share of entertainment service } & \multicolumn{3}{|c|}{ Budget share of necessities } \\
\hline & Catering & Entertainment & Necessities & $\begin{array}{l}\text { Income quantile } \\
20 \% \\
\text { below }\end{array}$ & $\begin{array}{l}\text { Income } \\
\text { quantile } \\
80 \% \text { above }\end{array}$ & $\begin{array}{l}\text { Income quantile } \\
60 \% \\
\text { middle }\end{array}$ & $\begin{array}{l}\text { Income quantile } \\
20 \% \\
\text { below }\end{array}$ & $\begin{array}{l}\text { Income } \\
\text { quantile } \\
80 \% \text { above }\end{array}$ & $\begin{array}{l}\text { Income quantile } \\
60 \% \\
\text { middle }\end{array}$ & $\begin{array}{l}\text { Income quantile } \\
20 \% \\
\text { below }\end{array}$ & $\begin{array}{l}\text { Income } \\
\text { quantile } \\
80 \% \text { above }\end{array}$ & $\begin{array}{l}\text { Income } \\
\text { quantile } \\
60 \% \text { middle }\end{array}$ \\
\hline \multirow[t]{2}{*}{ HHINCOME } & $1.52 \mathrm{E}-08$ & $1.51 \mathrm{e}-08^{*}$ & $-5.39 \mathrm{e}-09^{*}$ & -0.000000128 & $-1.58 \mathrm{e}-08$ & $0.000000389^{*}$ & $-6.41 \mathrm{e}-08$ & $-2.84 \mathrm{e}-09$ & $0.000000188^{* *}$ & -0.000000123 & $-2.26 \mathrm{e}-09$ & $7.31 \mathrm{e}-09$ \\
\hline & $(-2.09 \mathrm{E}-08)$ & $(-8.22 \mathrm{E}-09)$ & $(-2.99 \mathrm{E}-09)$ & $(0.000000972)$ & $(1.89 \mathrm{e}-08)$ & $(0.000000231)$ & $(0.000000207)$ & $(7.26 \mathrm{e}-09)$ & $(7.93 \mathrm{e}-08)$ & $(9.39 \mathrm{e}-08)$ & $(3.75 \mathrm{e}-09)$ & $(6.13 \mathrm{e}-08)$ \\
\hline $\begin{array}{l}\begin{array}{l}\text { Household } \\
\text { characteristics }\end{array} \\
\end{array}$ & $\sqrt{ }$ & $\sqrt{ }$ & $\sqrt{ }$ & $\sqrt{ }$ & v & $\sqrt{ }$ & $\sqrt{ }$ & $\sqrt{ }$ & v & $\sqrt{ }$ & $\sqrt{ }$ & $\sqrt{ }$ \\
\hline $\begin{array}{l}\text { Household } \\
\text { subjective } \\
\text { attitude }\end{array}$ & $\sqrt{ }$ & $\sqrt{ }$ & $\sqrt{ }$ & $\sqrt{ }$ & $\sqrt{ }$ & $\sqrt{ }$ & $\sqrt{ }$ & $\sqrt{ }$ & $\sqrt{ }$ & $\sqrt{ }$ & $\sqrt{ }$ & $\sqrt{ }$ \\
\hline \multirow[t]{2}{*}{ _cons } & $0.125^{* * *}$ & $-0.0448^{* * *}$ & $0.0537^{* * *}$ & $-0.238^{* *}$ & $0.327^{* * *}$ & $0.152^{* * *}$ & $-0.104^{* * *}$ & $0.110^{* * *}$ & $-0.0503^{* *}$ & $0.0756^{* * *}$ & $0.0619^{* *}$ & $0.0420^{* * *}$ \\
\hline & $(-0.0397)$ & $(-0.0146)$ & $(-0.0102)$ & $(0.102)$ & $(0.105)$ & $(0.0564)$ & $(0.0249)$ & $(0.0422)$ & $(0.0197)$ & $(0.0211)$ & $(0.0247)$ & $(0.0128)$ \\
\hline \multirow[t]{2}{*}{$\begin{array}{l}\text { Sigma } \\
\end{array}$} & $0.142^{* * *}$ & $0.0462^{* * *}$ & $0.0377^{* * *}$ & $0.163^{* * *}$ & $0.108^{* * *}$ & $0.145^{* * *}$ & $0.0352^{* * *}$ & $0.0507^{* * *}$ & $0.0411^{* * *}$ & $0.0337^{* * *}$ & $0.0373^{* * *}$ & $0.0383^{* * *}$ \\
\hline & $(-0.00506)$ & $(-0.00499)$ & $(-0.00203)$ & $(0.0136)$ & $(0.00679)$ & $(0.00638)$ & $(0.00404)$ & $(0.00789)$ & $(0.00517)$ & $(0.00512)$ & $(0.00429)$ & $(0.00224)$ \\
\hline $\mathrm{N}$ & 1310 & 1310 & 1310 & 258 & 258 & 794 & 260 & 262 & 797 & 258 & 258 & 794 \\
\hline
\end{tabular}

Notes. Standard errors are in parentheses; ${ }^{*}$ means statistically significant at the $10 \%$ level; ${ }^{* *}$ means statistically significant at the $5 \%$ level; ${ }^{* * *}$ means statistically significant at the $1 \%$ level. 
The regression results of catering services are shown in second three columns. For middle group and richest group, there is no significant evidence between formal and informal sector, but for the poorest $20 \%$ quintile, female partners spend less $6.09 \%$ than the household with formal employed wives, while for male partner it shows opposite effect, with $6.09 \%$ more expenditure, indicating that the budget constraint for poor family can change their consumption patterns, and women are more inclined to suffer from it. For male partners with higher education in the richest quintile, they are less likely to spend on catering which is in line with age group male 36-45 years old. For those in prime age, catering is treated like necessities, consequently, much time and budget has been transferred to tourist or education investment. For poorest families, those with children aged between 3-6 years old and 13-18 years old also spend less on catering, because they need to save money to afford their education as they are growing up.

The third three columns in Table 2 present the expenditure on entertainment services. In the poorest household group, it shows the same pattern compared with catering service, but the magnitude is much lower, with only about $1.76 \%$ higher for male partner and $1.78 \%$ lower for female partner. The similar pattern also appears in female partner education, but the effect has been doubled. For middle group, only higher education groups have $2.68 \%$ higher on entertainment service. While for the richest, the trend for male partner is still negative, but for female partner, it is negative compared with catering. It shows that women in different income distribution have different preference on time-consuming service. For the richer employees, they enjoy more flexible working time and better working environment; for poorest workers, they are mostly labor-intensive workers who need to suffer from long-working hours, leading them to cherish more on time-consuming goods. There appears a significantly positive effect $(2.95 \%)$ when poorest families have children 3-5 years old, and negative effect $(2.13 \%)$ when they grow up to $13-18$ with respect to no children in the household. In combination of catering and entertainment, poorest families save the money on catering for entertainment when children are younger and cut off budget on both of them to save money for education in the future. The same trend happens in the middle family but for age group of 7-12 years old. Compared with those negative effect, the richest always have positive sign on those expenditure although it is not much significant, which is in consistent with that they are not concerned too much on budget constraint.

Finally, the impact of employment status on the family expenditure of necessities shows different trend for richest people. For poorest family, it has no significant effect because those necessities maintain the basic living, so they are infinitely elastic which can hardly be affected by budget constraint. But for richest family, wives in informal sector tend to have $1.89 \%$ more on necessities, husbands with $2.39 \%$ lower. It shows that they enjoy better benefits in SOE or collective enterprise, especially for female who has maternity benefits.

\section{Conclusions}

The purpose of the paper is to investigate the impact of informal employment status on the consumption and how those impacts vary with the income distribution. The authors find that there is significantly different gender preference on consumption patterns for employees who worked in informal sector. After considering different income quantile, for time-saving goods, family where wife is informal employed tends to reduce their expenditure on time-saving goods, while there is a significant raise if the husband is informal employed. And such pattern is more significant in the poorest income groups compared with higher income groups. For time-consuming goods as entertainment services, poorest families where wife is in informal employed tend to reduce their expenditure share on it, while there is also a significant raise if the husband is informal employed. 
Richest families are not as much constrained as those in poorest families due to less budget constraint as well as time constraint. For necessities, families with wives working in formal sector enjoy much better fringe benefits. In addition, concerning the demographic characteristics of the household members, especially the educational attainment, both female and male spouse have positive impacts on the time-saving and time-intensive goods, while there is not significant effect on time-neutral goods. The presence and age of children in the household have a significant effect on time-saving goods. The household subjective factors play an important role on expenditure on time-saving goods, especially for the poorest household.

\section{References}

Banerjee, B. (1983). The role of the informal sector in the migration process: A test of probabilistic migration models and labour market segmentation for India. Oxford Economic Papers, 35(3), 399-422.

Chen, J., Aung, M., Zhou, L., \& Kanetkar, V. (2005). Chinese ethnic identification and conspicuous consumption: Are there moderators or mediators effect of acculturation dimensions? Journal of International Consumer Marketing, 17(2-3), 117-136.

Cui, G., \& Liu, Q. (2000). Regional market segments of China: Opportunities and barriers in a big emerging market. Journal of Consumer Marketing, 17(1), 55-72.

Dickson, M. A., Lennon, S. J., Montalto, C. P., Shen, D., \& Zhang, L. (2004). Chinese consumer market segments for foreign apparel products. Journal of Consumer Marketing, 21(5), 301-317.

Fields, G. S. (1975). Rural-urban migration, urban unemployment and underemployment, and job-search activity in LDCs. Journal of Development Economics, 2(2), 165-187.

Gould, B. W., \& Villarreal, H. J. (2006). An assessment of the current structure of food demand in urban China. Agricultural Economics, 34(1), 1-16.

Min, I., Fang, C., \& Li, Q. (2004). Investigation of patterns in food-away-from-home expenditure for China. China Economic Review, 15(4), 457-476.

International Labour Office (ILO). (1984). Urbanisation, informal sector and employment: A progress report on research. Advisory Services and Technical Cooperation, World Employment Programme, Geneva.

Ma, H., Huang, J., Fuller, F., \& Rozelle, S. (2006). Getting rich and eating out: Consumption of food away from home in urban China. Canadian Journal of Agricultural Economics/Revue canadienne d'agroeconomie, 54(1), 101-119.

Mazumdar, D. (1977). Analysis of the dual labour market in LDCs. In S. Kannappan (Ed.), Studies in urban labour market behaviour in developing areas (pp. 13-33). Geneva: International Institute for Labour Studies, ILO.

Sun, Q., Tong, W., \& Yu, Q. (2002). Determinants of foreign direct investment across China. Journal of International Money and Finance, 21(1), 79-113.

Sun, T., \& Wu, G. (2004). Consumption patterns of Chinese urban and rural consumers. Journal of Consumer Marketing, 21(4), 245-253.

Sun, T., Chang, T. K., \& Yu, G. (2001). Social structure, media system, and audiences in China: Testing the uses and dependency model. Mass Communication \& Society, 4(2), 199-217.

Todaro, M. P. (1969). A model of labor migration and urban unemployment in less developed countries. The American Economic Review, 59(1), 138-148.

Wei, R. (1997). Emerging lifestyles in China and consequences for perception of advertising, buying behavior and consumption preferences. International Journal of Advertising, 16(4), 261-275.

Wei, Y., Liu, X., Parker, D., \& Vaidya, K. (1999). The regional distribution of foreign direct investment in China. Regional Studies, 33(9), 857-867.

Ying, B., \& Yao, R. (2006). Consumption patterns of Chinese elders: Evidence from a survey in Wuhan, China. Journal of Family and Economic Issues, 27(4), 702-714.

Yusuf, F., \& Brooks, G. (2010). Demographics and consumption patterns in urban China. Population Research and Policy Review, 29(1), 5-17.

Yusuf, S., \& Wu, W. (1997). The dynamics of urban growth in three Chinese cities. World Bank Publication, Oxford University Press. 